\title{
Feasibility of quantitative inorganic arsenic speciation at the parts-per-trillion level using solid phase extraction and femtosecond laser ablation inductively coupled plasma mass spectrometry
}

\author{
Seon Hwa Lee, Seon-Jin Yang, Yonghoon Lee ${ }^{*}$ and Sang-Ho Nam ${ }^{*}$ (i)
}

\begin{abstract}
Toxicity of arsenic compounds depends on the chemical structure as well as the concentration. Thus, separation of the toxic arsenic species should precede the quantification for the accurate toxicity assessment. Ion chromatography inductively coupled plasma mass spectrometry (IC-ICP-MS) has been the most popular method for separation and quantification of toxic arsenic species. However, the method requires complex instrument, elaborate sample preparation, and long analysis time. In this work, toxic inorganic arsenic species in water was separated by the simple solid phase extraction (SPE) using a strong anion-exchange membrane filter, and then the membrane filter was analyzed by femtosecond laser ablation inductively coupled plasma mass spectrometry (fs-LA-ICP-MS). The $\mathrm{pH}$ value of the sample was adjusted to 4 using ammonium hydroxide and phosphoric acid for the complete separation of the toxic inorganic arsenic from the other organic arsenics. The linear dynamic range was from 0.5 to $1000 \mu \mathrm{g} / \mathrm{kg}$, and the correlation coefficient was 0.99989 . The recovery efficiency was $96-106 \%$. The detection limit of the inorganic arsenic was $0.028 \mu \mathrm{g} / \mathrm{kg}$. Our results indicate that SPE-fs-LA-ICP-MS provides enough analytical performance to analyze the toxic inorganic arsenic in water at the level of parts per trillion using the simple separation method and the rapid laser ablation sampling.
\end{abstract}

Keywords: Fs-LA-ICP-MS, Solid phase extraction, Arsenic toxicity, Inorganic arsenic, Arsenic speciation

\section{Introduction}

Arsenic has a single isotope $\left({ }^{75} \mathrm{As}\right)$ and is the 53rd most abundant element $(1.5 \mathrm{mg} / \mathrm{kg})$ in the earth's crust (Audi et al. 2003; Haynes 2016). The main sources of human exposure to arsenic are known as food, water, soil, and air (ATSDR. 2006). Arsenic can exist in any environmental and biological systems in a variety of forms; it can remain in plants or shellfish grown in arseniccontaminated water or soil and enter the human body through the food chain (Tamaki and Frankenberger

\footnotetext{
* Correspondence: yhlee@mokpo.ac.kr; shnam@mokpo.ac.kr

Department of Chemistry, Mokpo National University, 1666 Yeongsan-ro, Cheonggye-myeon, Muan-gun, Jeonnam 58554, Republic of Korea
}

1992). Depending on the degree of exposure to arsenic, it may cause symptoms of arsenic poisoning. The chronic arsenic exposure is known to cause diseases such as diabetes, cardiovascular disease, and cancers of the skin and internal organs (Martinez et al. 2011). In Bangladesh, for example, 40,000 people died of chronic arsenic exposure ( $5.6 \%$ of the dead each year) (Flanagan et al. 2012). For this reason, there is a great interest in arsenic in various fields including both manufacturing and agricultural industries. The relative toxicity of arsenic depends on the concentration, the oxidation state, and the organic or inorganic state of the species (ATSD R. 2006). Arsenic combined with oxygen or sulfur is 
called "inorganic arsenic" and that combined with carbon and hydrogen is called "organic arsenic" (ATSDR. 2007).

Arsenic trioxide $\left(\mathrm{As}_{2} \mathrm{O}_{3}\right)$, sodium arsenite $\left(\mathrm{NaAsO}_{2}\right)$, and arsenic trichloride $\left(\mathrm{AsCl}_{3}\right)$ are the most common trivalent inorganic arsenic compounds, and arsenic pentoxide $\left(\mathrm{As}_{2} \mathrm{O}_{5}\right)$, arsenic acid $\left(\mathrm{H}_{3} \mathrm{AsO}_{4}\right)$, and arsenates such as lead hydrogen arsenate $\left(\mathrm{PbHAsO}_{4}\right)$ and calcium arsenate $\left(\mathrm{Ca}_{3}\left(\mathrm{AsO}_{4}\right)_{2}\right)$ are known to be the most common pentavalent inorganic arsenics (IARC. 2012). Inorganic arsenic species such as arsenite $\left(\mathrm{As}^{3+}\right)$ and arsenate $\left(\mathrm{As}^{5+}\right)$ are more toxic than organic arsenic species such as monomethyl-arsonic acid (MMA, $\mathrm{CH}_{5} \mathrm{AsO}_{3}$ ) and dimethylarsinic acid (DMA, $\mathrm{C}_{2} \mathrm{H}_{7} \mathrm{AsO}_{2}$ ) (Ratnaike 2003; Todorov et al. 2005; Chen and Chen 2014). In particular, arsenobetaine (AsB, $\left.\mathrm{C}_{5} \mathrm{H}_{11} \mathrm{AsO}_{2}\right)$ and arsenocholine (AsC, $\mathrm{C}_{5} \mathrm{H}_{14} \mathrm{AsO}^{+}$), also called "fish arsenic," are found mainly in fish and shellfish and known to be nontoxic (Tamura et al. 2010; Cullen \& Reimer 1989). Currently, the arsenic toxicity is assessed on the basis of total inorganic arsenics $(\mathrm{As}(\mathrm{III})+\mathrm{As}(\mathrm{V}))$ excluding less toxic organic arsenics (Llorente-Mirandes et al. 2017). Chromatographic methods have been mainly used for the separation of inorganic arsenic species from organic ones so far. Liquid chromatography, high resolution liquid chromatography, gas chromatography, and ion chromatography have been used for this purpose (Nam et al. 2003; Son et al. 2019; Lee et al. 2019). However, these methods consume a large amount of solvent and take a long time to separate species. The Joint FAO/WHO Expert Committee on Food Additives (JECFA) has shown a large fluctuation in inorganic arsenic content in a sample, and there is still insufficient verification of the analysis method. It was decided that these problems should be improved (Yang et al. 2016; Choi et al. 2010). The solid phase extraction (SPE) method has been considered as an alternative to simplify the separation process. SPE is generally used for separation, concentration, or purification of substances to be analyzed. The type and shape of the SPE method used are different depending on the samples. Consideration should be given to the total volume of the sample, the degree of contamination, the complexity, type and strength of the matrix, and the amount of material to be analyzed. Types of ion exchange that can be used for SPE include strong anion exchange (SAX), weak anion exchange (WAX), strong cation exchange (SCX), and weak cation exchange (WCX). Among these ionexchange types, the efficiency of the separation of inorganic arsenic species by the SAX membrane has been investigated previously (Nazaratul and Amares
2011). Herein, SAX was chosen to selectively adsorb toxic inorganic arsenic species.

Recently, inorganic arsenics in water have been separated using the ion-exchange membranes, and detected by laser-induced breakdown spectroscopy (LIBS) (Nam et al. 2018). This method was able to separate inorganic arsenic species in a simpler way than the conventional chromatographic methods used for arsenic species analysis. However, the limit of detection (LOD) of this method is $10 \mathrm{mg} / \mathrm{kg}$, which is not suitable for the analysis of trace amounts of inorganic arsenic present in real food or environmental samples. LA-ICP-MS is one of the leading technologies for the analysis of elemental and isotopic compositions of various materials. The surface of the sample is irradiated with a laser beam to generate fine particles. The generated particles are transported to the plasma for ionization and the ions are analyzed by the mass spectrometer (Chichkov et al. 1996; Russo et al. 1999). Although LA-ICP-MS and LIBS use the sample sampling method, the laser ablation, the mass spectrometric detection of LA-ICP-MS shows the better LOD performance than the optical emission detection of LIBS. The laser systems used for LA-ICP-MS are largely classified into nanosecond (ns) and femtosecond (fs) ones according to their pulse duration. Nanosecond lasers are widely used for LIBS or LA-ICP-MS. However, the major drawback of LA-ICP-MS using a nanosecond laser is the incomplete atomization of the ablated matter due to thermal effect, which results in significant deviation from the stoichiometric ablation (Lahaye et al. 2015). Femtosecond lasers can mitigate the effect on fractionation of elements, reduce thermal effects, directly break chemical bonds, and reduce sample damages (Chichkov et al. 1996; Diwakar et al. 2013). The ion-exchange membrane used in this work is about $0.5 \mathrm{~mm}$ thick and can easily be damaged by weak impacts. Thus, the use of fs-LA-ICP-MS would be more appropriate than nsLA-ICP-MS. In this work, femtosecond laser ablation inductively coupled plasma mass spectrometry (fsLA-ICP-MS) was used to improve the LOD performance for the analysis of inorganic arsenic species separated from aqueous solution by the ion-exchange membrane. To analyze total inorganic arsenics $(\mathrm{As}(\mathrm{III})+\mathrm{As}(\mathrm{V}))$, As(III) species was oxidized to $\operatorname{As}(\mathrm{V})$, and the resulting $\operatorname{As}(\mathrm{V})$ species was separated from the other organic species using the ionexchange membrane. Then, the ion-exchange membrane was analyzed by fs-LA-ICP-MS to measure the mass signal intensity of ${ }^{75} \mathrm{As}$. Our results indicate that the SPE-fs-LA-ICP-MS is a feasible methodology for the parts-per-trillion-level analysis of total inorganic arsenics $(\mathrm{As}(\mathrm{III})+\mathrm{As}(\mathrm{V}))$ for arsenic toxicity assessment. 


\section{Materials and methods}

\section{lon-exchange membrane filter disk}

The ion-exchange membrane filter disk (Empore ${ }^{\mathrm{TM}}$, SPE disk, diameter $47 \mathrm{~mm}, 29 \mathrm{M}$ Corp.) was used for the separation of inorganic arsenic. The membrane polymer has positively charged quaternary ammonium groups so it is used for anion exchange. The membrane was fixed to glass funnel, and the conditioning of membrane was progressed according to manual (3M SPE Technical Information). For conditioning the membrane, acetone, methanol, deionized water, sodium hydroxide solution $(1 \mathrm{M})$, and deionized water were passed through it in this order. After samples passed through the conditioned membrane, it was dried in the oven at $40{ }^{\circ} \mathrm{C}$ for $2 \mathrm{~h}$.

\section{Reagent}

All samples were made using deionized water. Stock solutions of calibration standards and samples were made using the following reagents. Sodium arsenate dibasic heptahydrate $\left(\mathrm{Na}_{2} \mathrm{HAsO}_{4} \cdot 7 \mathrm{H}_{2} \mathrm{O}, \geq 98 \%\right.$, Sigma-Aldrich), sodium (meta)arsenite $\left(\mathrm{NaAsO}_{2}, 98 \%\right.$, Sigma-Aldrich), and sodium cacodylate $\left(\left(\mathrm{CH}_{3}\right)_{2} \mathrm{AsO}_{2} \mathrm{Na}, \geq 98 \%\right.$, SigmaAldrich) were used to prepare the stock solutions for $\mathrm{As}(\mathrm{V})$, As(III), and DMA, respectively. The concentrations of stock solutions were $0.9903 \mathrm{mg} / \mathrm{kg} \mathrm{As}(\mathrm{V})$, $0.9920 \mathrm{mg} / \mathrm{kg}$ As(III), and $0.9652 \mathrm{mg} / \mathrm{kg}$ DMA and diluted with deionized water as needed for the calibration standards. To adjust $\mathrm{pH}$ of the sample solution, phosphoric acid $\left(\mathrm{H}_{3} \mathrm{PO}_{4}, 85-90 \%\right.$, Honeywell/Fluka) and ammonium hydroxide $\left(\mathrm{NH}_{4} \mathrm{OH}, 28 \% \mathrm{NH}_{3}\right.$ in $\mathrm{H}_{2} \mathrm{O}$, SigmaAldrich) solutions were used.

\section{Procedure}

Before introducing the sample for arsenic speciation, conditioning of membrane is necessary. Acetone $(\geq$ 99.9\%, HPLC grade, Sigma-Aldrich), methanol ( $\geq 99.9 \%$, HPLC grade, Daejung), deionized water, sodium hydroxide solution $(1 \mathrm{M})$, and deionized water were passed in order through the membrane. Then, the sample solution was passed through the conditioned membrane. At this time, the flow rate $(\leq 2 \mathrm{~mL} / \mathrm{min})$ was adjusted using glass funnel combined with manual decompression device. After the sample solution was passed through the membrane filter, it was dried in the oven at $40{ }^{\circ} \mathrm{C}$ for 2 $\mathrm{h}$ and then analyzed by LA-ICP-MS. Arsenic species in the solution which was passed through the membrane was also analyzed by IC-ICP-MS.

\section{Instrument}

\section{Fs-LA-ICP-MS}

The fs-LA-ICP-MS was used for the analysis of the adsorbed arsenic on the membrane filter. A commercial laser ablation system (Applied Spectra, Inc., Sacramento, CA, USA) was used. Laser wavelength was $1030 \mathrm{~nm}$. A mixture of helium and argon was used as a carrier gas. ICP-MS (ICAP TQ, Thermo fisher scientific, ISA, Waltham) was used for the detection of arsenic species. The operating parameters of fs-LA-ICP-MS were shown in Table 1.

\section{IC-ICP-MS}

The IC-ICP-MS was used to identify the arsenic species present in the solution which passed through the membrane. A GS-50 pump (DIONEX, Sunnyvale, CA, USA) was used to inject the sample solution. A Hamilton PRP-X100 column was used for arsenic speciation. ICPMS (SPECTRO MS, SPECTRO, Kleve, Germany) was used for the detection of arsenic present in the sample. Table 2 showed the operating parameters of IC-ICP-MS.

\section{Results and discussion}

Signal intensity distribution on the ion-exchange membrane filter

Diameter and thickness of the ion-exchange membrane filter were $47 \mathrm{~mm}$ and $0.5 \mathrm{~mm}$, respectively. The $\mathrm{As}(\mathrm{V})$ should be homogeneously adsorbed on the membrane filter which was conditioned and dried. To check the homogeneity of the $\mathrm{As}(\mathrm{V})$ absorbed on the membrane filter, the ${ }^{75}$ As mass signals were measured through twelve line scans on different places on the membrane filter by fs-LA-ICP-MS. A preconditioned ion-exchange membrane was used to filter $10 \mathrm{~mL}$ of the aqueous solution of $\mathrm{As}(\mathrm{V})$ of which concentration is $100 \mu \mathrm{g} / \mathrm{kg}$. The length and position of each

Table 1 Operating parameters for fs LA-ICP-MS

\begin{tabular}{ll}
\hline Parameter & Condition \\
\hline Laser ablation system & $1030 \mathrm{~nm}$ \\
Laser wavelength & $50 \%$ \\
Output level & $100 \mathrm{~Hz}$ \\
Laser repetition rate & \\
Gas flow rate & $1.0 \mathrm{~L} / \mathrm{min}$ \\
He gas & $0.7 \mathrm{~L} / \mathrm{min}$ \\
Ar gas & $50 \mu \mathrm{m}$ \\
Beam size & $0.1 \mathrm{~mm} / \mathrm{s}$ \\
Scan speed & $2 \mathrm{~mm}$ \\
Scan length & \\
ICP-MS & $1550 \mathrm{~W}$ \\
RF plasma power & \\
Argon gas flow rate & $14 \mathrm{~L} / \mathrm{min}$ \\
Coolant flow & $0.8 \mathrm{~L} / \mathrm{min}$ \\
Auxiliary flow & $1.0 \mathrm{~L} / \mathrm{min}$ \\
Nebulizer flow & $\mathrm{Cross}$ flow \\
Nebulizer & As 74.9 \\
Monitor $m / z$ & \\
\hline
\end{tabular}


Table 2 Operating parameters for IC-ICP-MS

\begin{tabular}{ll}
\hline Parameter & Condition \\
\hline ICP-MS & \\
RF plasma power & $1450 \mathrm{~W}$ \\
Argon gas flow rate & \\
Coolant flow & $14 \mathrm{~L} / \mathrm{min}$ \\
Auxiliary flow & $0.8 \mathrm{~L} / \mathrm{min}$ \\
Nebulizer flow & $1.0 \mathrm{~L} / \mathrm{min}$ \\
Nebulizer & Concentric \\
Monitor $\mathrm{m} / \mathrm{z}$ & As 74.9 \\
IC & \\
Analytical column & Hamilton PRP-X100 $(10 \mu \mathrm{m}, 4.6 \times 250 \mathrm{~mm})$ \\
Flow rate & $1.0 \mathrm{~mL} / \mathrm{min}$ \\
Sample loop & $100 \mu \mathrm{L}$ \\
Mobile phase & $20 \mathrm{mM}$ ammonium phosphate $(\mathrm{pH} 6.0)$ \\
\hline
\end{tabular}

line scan were shown in Fig. 1a. The 2-mm long line scans were separated from one another by $3 \mathrm{~mm}$. The ${ }^{75}$ As mass signal intensities resulting from the $\mathrm{As}(\mathrm{V})$ adsorbed on the membrane filter are shown in Fig. 1b. The line scan position and the corresponding mass signal were indicated by the same number in Fig. 1. For each line-scan analysis, we took one intensity value that is integrated area under each mass signal profile in Fig. 1b. Then, the average and the standard deviation of the twelve intensity values were obtained. The RSD value was calculated as the ratio of the standard deviation to the average. The RSD for the signal intensities of $\mathrm{As}(\mathrm{V})$ recorded by the twelve line scans was 5.5\%, which can be regarded as the measurement precision. It indicated that the $\mathrm{As}(\mathrm{V})$ species were homogeneously adsorbed within this uncertainty.

\section{Calibration curve and analytical performances}

In our previous study (Nam et al. 2018), the inorganic arsenic was measured by ion-exchange membrane and LIBS. The linear dynamic range was from 20 to $500 \mathrm{mg} /$ $\mathrm{kg} \mathrm{As}(\mathrm{V})$, and the LOD was $10 \mathrm{mg} / \mathrm{kg} \mathrm{As}(\mathrm{V})$. The LOD performance provided by LIBS would not be enough for practical toxicity assessment. Environmental Protection Agency (EPA) of United States set the maximum contamination level (MCL) for arsenic in drinking water to be $10 \mu \mathrm{g} / \mathrm{kg}$ (Arsenic and clarification to compliance and new source monitoring rule: a quick reference guide 2001), which is far below the LOD provided by the previously reported SPE-LIBS method. The calibration curve of the inorganic arsenic obtained by fs-LA-ICPMS is shown in Fig. 2a. Eight standard solutions of 0.5, $1,5,10,50,100,500$, and $1000 \mu \mathrm{g} / \mathrm{kg} \mathrm{As}(\mathrm{V})$ were used for SPE and the ion-exchange membrane filters were analyzed for this calibration curve. The experimentally measured values were fitted using a linear function. The fitted parameters, slope, and intercept are noted in Fig. 2a. The correlation coefficient, $R^{2}$, was 0.99989 . So, the linear dynamic range is confirmed in the concentration range from 0.5 to $1000 \mu \mathrm{g} / \mathrm{kg} \mathrm{As}(\mathrm{V})$. The LOD of $\mathrm{As}(\mathrm{V})$ was estimated to be $0.028 \mu \mathrm{g} / \mathrm{kg}$ using the equation, $3 \sigma / s . \sigma$ is the standard deviation of the intensities measured for the standard prepared using the aqueous solution of $0.5 \mu \mathrm{g} / \mathrm{kg} \mathrm{As}(\mathrm{V}) . s$ is the slope of the
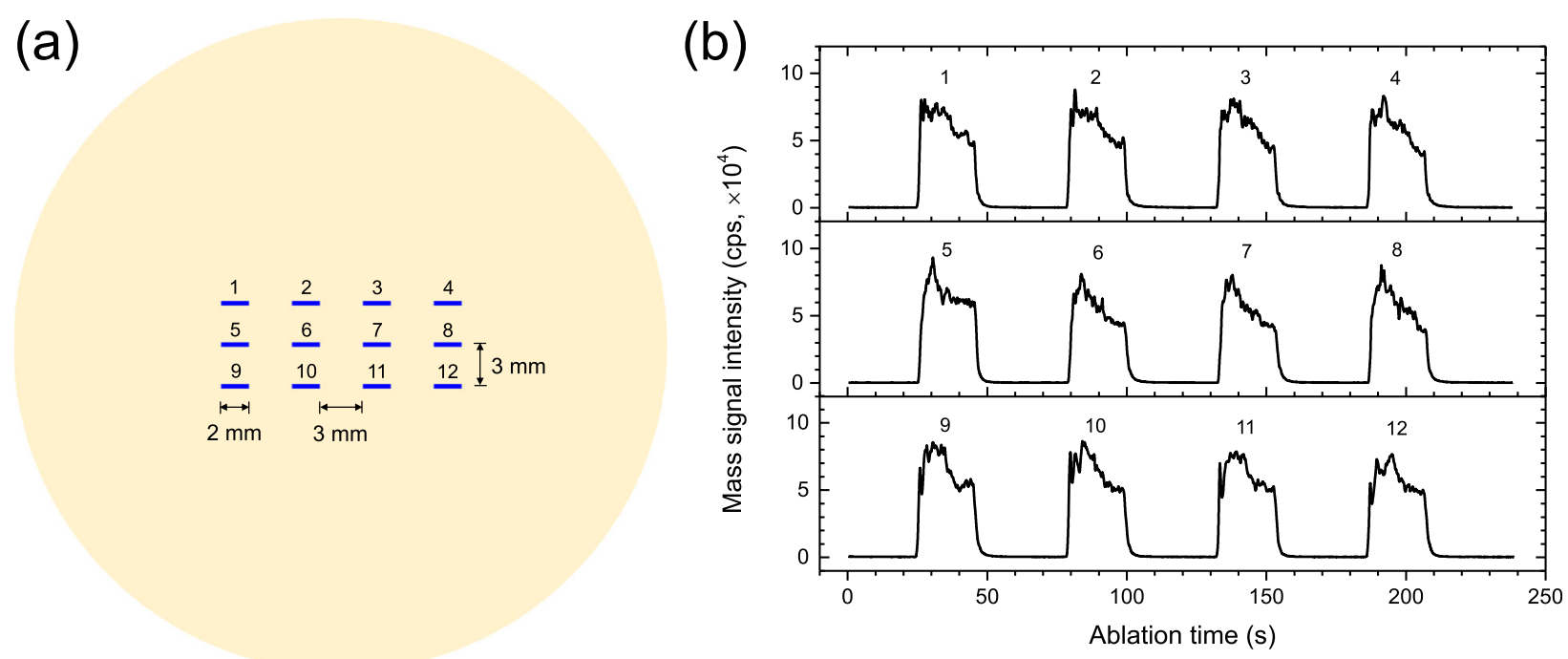

Fig. 1 (a) Twelve line-scan positions on the ion-exchange membrane filter surface and (b) the corresponding ${ }^{75}$ As mass signal intensity profiles obtained by fs LA-ICP-MS. In a, the blue lines represent the 2-mm long line-scan positions. The line-scan position and the corresponding mass signal profile are indicated by the same number 

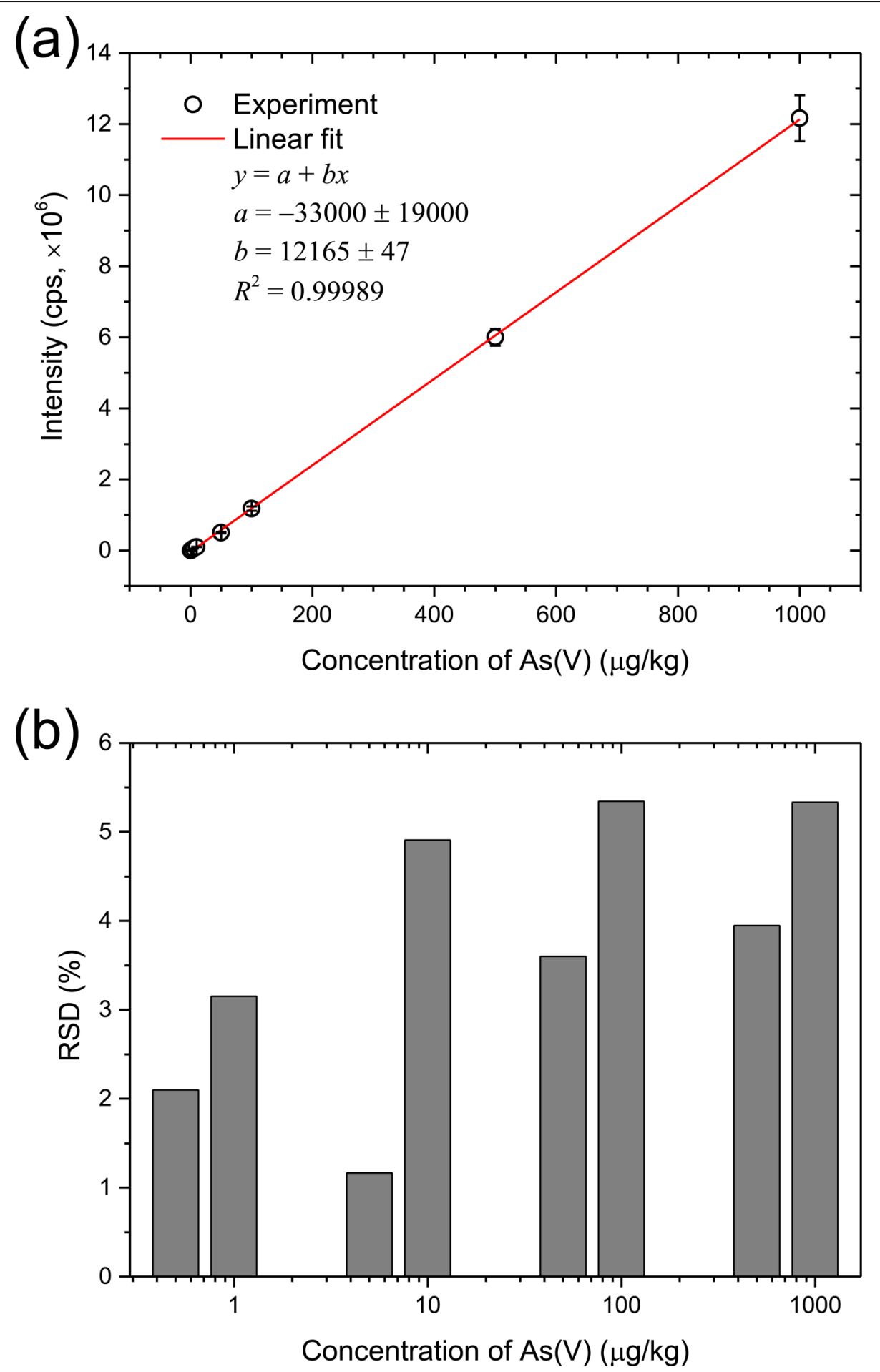

Fig. 2 (a) Calibration curve for As(V) absorbed in the SPE filter disk obtained by fs-LA-ICP-MS and (b) RSD values estimated for the corresponding standards. The error bar in a represents the standard deviation value obtained from four repetitive measurements for each standard

calibration curve. Considering the MCL of arsenic set by EPA, the LOD performance of our SPE-fs-LA-ICP-MS method is found to be enough for its application to the arsenic toxicity assessment for drinking water. The bar graph in Fig. $2 \mathrm{~b}$ shows the RSD values at the corresponding standards. The RSD ranges from 1.2 to $5.3 \%$.

It should be noted that our method provided the remarkably low LOD of inorganic arsenic dissolved in 
water $(0.028 \mu \mathrm{g} / \mathrm{kg})$. The LOD of inorganic arsenic in water was estimated to be $0.13 \mu \mathrm{g} / \mathrm{kg}$ by IC-ICP-MS in our laboratory. Thus, the SPE-fs-LA-ICP-MS method is found to provide the LOD performance even better than that of the conventional IC-ICP-MS analysis for water. Also, the typical LODs that can be reached by fs-LAICP-MS for solid samples are at the level of a few to several ten microgram per kilogram (Vanhaecke et al. 2010; Li et al. 2016). The LOD estimated for As(V) dissolved in water can be converted to the corresponding value for $\mathrm{As}(\mathrm{V})$ adsorbed the solid ion-exchange membrane. A $10-\mathrm{mL}$ of the aqueous solution was filtered by each membrane filter that weighs $0.2673 \pm 0.0080 \mathrm{~g}$. Thus, the corresponding LOD of $\mathrm{As}(\mathrm{V})$ adsorbed on the solid ion-exchange membrane filter is estimated to be $1.1 \mu \mathrm{g} /$ $\mathrm{kg}$. This is similar to the typical LODs of fs-LA-ICP-MS for solid samples. Therefore, the low LOD of inorganic arsenic achieved in this work can be attributed to the preconcentration effect during the SPE process. The preconcentration factor is 37.4 (= $10 \mathrm{~g}$ water/0.2673 $\mathrm{g}$ ionexchange membrane filter).

\section{Recovery of As(V) by SPE and fs-LA-ICP-MS}

Several standard solutions were used to investigate the recovery of $\mathrm{As}(\mathrm{V})$ in our method. They were mainly prepared with the $A s(\mathrm{III})$ and $A s(\mathrm{~V})$ standards while one standard solution was made by the mixture of As(III), $\operatorname{As}(\mathrm{V})$, and DMA. The mixture was used to make sure that the inorganic arsenic was well separated from the organoarsenic. The inorganic arsenic was the total of $\mathrm{As}(\mathrm{III})$ and $\mathrm{As}(\mathrm{V})$ as the $\mathrm{As}(\mathrm{III})$ was oxidized to $\mathrm{As}(\mathrm{V})$ by hydrogen peroxide. First, the recovery efficiencies of the samples containing only $\mathrm{As}(\mathrm{V})$ species were investigated. Two sample solutions with $20.1 \mu \mathrm{g} / \mathrm{kg} \mathrm{As}(\mathrm{V})$ and $62.3 \mu \mathrm{g} / \mathrm{kg} \mathrm{As}(\mathrm{V})$ were prepared for this experiment. Each sample solution was filtrated through the ionexchange membrane, the dried membrane was analyzed by fs-LA-ICP-MS, and the measure ${ }^{75}$ As mass signal was converted to the concentration using the calibration curve shown in Fig. 2. As the results are shown in Table 3, the recoveries of $20.1 \mu \mathrm{g} / \mathrm{kg}$ and $62.3 \mu \mathrm{g} / \mathrm{kg}$ As $(\mathrm{V})$ were $104 \%(=20.9 \mu \mathrm{g} / \mathrm{kg} \mathrm{As}(\mathrm{V}) / 20.1 \mu \mathrm{g} / \mathrm{kg} \mathrm{As}(\mathrm{V})$ $\times 100 \%)$ and $106 \%(=66.3 \mu \mathrm{g} / \mathrm{kg} \mathrm{As}(\mathrm{V}) / 62.3 \mu \mathrm{g} / \mathrm{kg} \mathrm{As}(\mathrm{V})$ $\times 100 \%)$, respectively. It indicates that almost all of the
$\mathrm{As}(\mathrm{V})$ in a water was adsorbed on the anionic separator filter and quantitatively measured by fs-LA-ICPMS. Second, the complete oxidation of As(III) to $\mathrm{As}(\mathrm{V})$ by hydrogen peroxide was confirmed by the following experiment. The sample solution containing $10.0 \mu \mathrm{g} / \mathrm{kg} \mathrm{As}(\mathrm{III})$ and $10.0 \mu \mathrm{g} / \mathrm{kg} \mathrm{As}(\mathrm{V})$ was prepared. Prior to being analyzed, the As(III) was oxidized to $\operatorname{As}(\mathrm{V})$ by hydrogen peroxide. The sample treated by hydrogen peroxide was then filtrated through the ion-exchange membrane, the ${ }^{75} \mathrm{As}$ mass signal intensity was measured by fs-LA-ICP-MS, and the mass signal intensity was converted to the concentration of As using the calibration shown in Fig. 2. The obtained concentration value was $19.3 \pm 2.4 \mu \mathrm{g} /$ $\mathrm{kg}$. Finally, the corresponding recovery value was calculated as $19.3 \mu \mathrm{g} / \mathrm{kg}$ of total inorganic arsenic/(10.0 $\mu \mathrm{g} / \mathrm{kg}$ As(III) $+10.0 \mu \mathrm{g} / \mathrm{kg} \mathrm{As}(\mathrm{V})) \times 100 \%=96.5 \%$. Finally, the selective oxidation of As(III), not DMA, to $\mathrm{As}(\mathrm{V})$ by hydrogen peroxide was confirmed by the experiment with the sample solution containing 10.0 $\mu \mathrm{g} / \mathrm{kg} \mathrm{As}(\mathrm{III}), 9.9 \mu \mathrm{g} / \mathrm{kg} \mathrm{As}(\mathrm{V})$, and $20.0 \mu \mathrm{g} / \mathrm{kg}$ DMA. Ideally, the concentration from SPE-fs-LA-ICP-MS should be $20.0 \mu \mathrm{g} / \mathrm{kg}$ which is the sum of $10.0 \mu \mathrm{g} / \mathrm{kg}$ $\mathrm{As}(\mathrm{III})$ and $9.9 \mu \mathrm{g} / \mathrm{kg} \mathrm{As}(\mathrm{V})$. The resulting concentration was $19.6 \pm 1.3 \mu \mathrm{g} / \mathrm{kg}$. The corresponding recovery of total inorganic in a sample made by $\mathrm{As}(\mathrm{III})$, As(V), and DMA was $98 \%$ of $10.0 \mu \mathrm{g} / \mathrm{kg} \mathrm{As}(\mathrm{III})$ and $9.9 \mu \mathrm{g} / \mathrm{kg} \mathrm{As}(\mathrm{V})$. This result indicates that the separation of the inorganic arsenic species from DMA was well completed by the anionic separator filter. Consequently, the SPE method employed in this work was found to be effective in separating the inorganic arsenics, As(III) and As(V), from the organic ones with the recovery efficiency close to $100 \%$.

\section{Separation of inorganic arsenic from the organoarsenic}

In this study, As(V) was measured by fs-LA-ICP-MS after it was separated from DMA by ion-exchange membrane filter. It is necessary to confirm the complete separation of $\mathrm{As}(\mathrm{V})$ from DMA. Thus, the chromatograms for $10 \mu \mathrm{g} / \mathrm{kg}$ As(III), DMA, MMA, and As(V) standards were obtained by IC-ICP-MS as the results were shown in the Fig. 3. Arsenobetaine standard was used as an internal standard.

Table 3 Determination of As(V) absorbed on the SPE filter disk by fs-LA-ICP-MS

\begin{tabular}{llll}
\hline $\begin{array}{l}\text { Concentration of } \mathbf{A s}(\mathbf{V}) \\
(\boldsymbol{\mu g} / \mathbf{k g})\end{array}$ & $\begin{array}{l}\text { Concentration of DMA } \\
(\boldsymbol{\mu} \mathbf{g} / \mathbf{k g})\end{array}$ & $\begin{array}{l}\text { Results } \\
(\boldsymbol{\mu g} / \mathbf{k g})\end{array}$ & $\begin{array}{l}\text { Recovery } \\
(\%)\end{array}$ \\
\hline 20.1 & - & $20.9 \pm 2.7$ & 103.8 \\
62.3 & - & $66.3 \pm 9.5$ & 106.4 \\
$20.0^{1}$ & - & $19.3 \pm 2.4$ & 96.4 \\
$19.9^{2}$ & 20.0 & $19.6 \pm 1.3$ & 98.3 \\
\hline
\end{tabular}

${ }^{1} 10.0 \mu \mathrm{g} / \mathrm{kg} \mathrm{As}(\mathrm{III}), 10.0 \mu \mathrm{g} / \mathrm{kg} \mathrm{As}(\mathrm{V})$, and hydrogen peroxide in the solution

${ }^{2} 10.0 \mu \mathrm{g} / \mathrm{kg} \mathrm{As}(\mathrm{III}), 9.9 \mu \mathrm{g} / \mathrm{kg} \mathrm{As}(\mathrm{V}), 20.0 \mu \mathrm{g} / \mathrm{kg} \mathrm{DMA}$, and hydrogen peroxide in the solution 


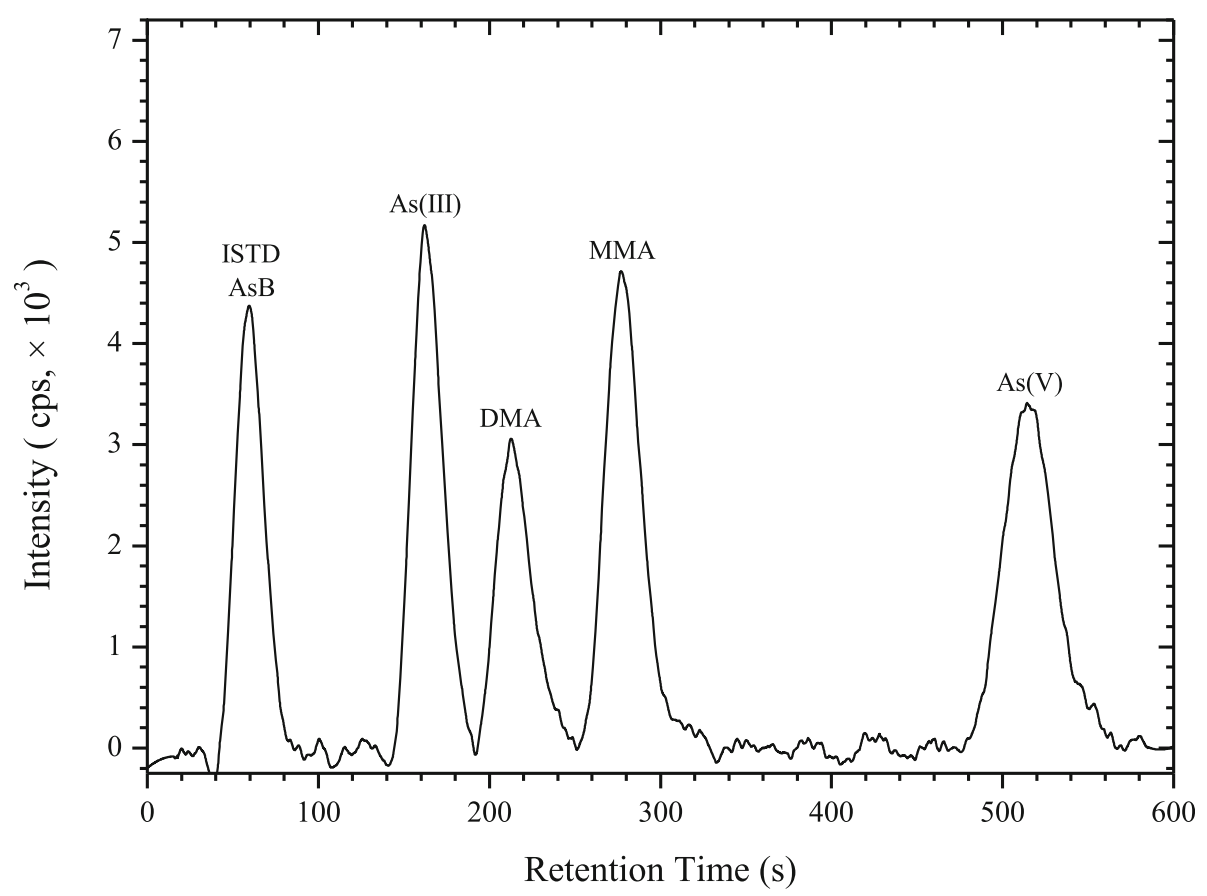

Fig. 3 Chromatogram of $10 \mu \mathrm{g} / \mathrm{kg}$ standard arsenic species by IC-ICP-MS

The mixture of $\operatorname{As}(\mathrm{V})$ and DMA with internal standard was prepared and passed through the anion-exchange filter. The filtered solution was injected into the IC-ICP-MS. As the result was shown in Fig. 4, there was no peak corresponding to $\mathrm{As}(\mathrm{V})$ and on the other hand a clear peak of DMA was observed. This was because DMA passed through the anion-exchange filter and $\mathrm{As}(\mathrm{V})$ was absorbed on it. Recoveries for DMA were measured by IC-ICP-MS. As the results were shown in Table 4, the recoveries ranged from 103 to $109 \%$. These results indicated that the simple SPE method separated

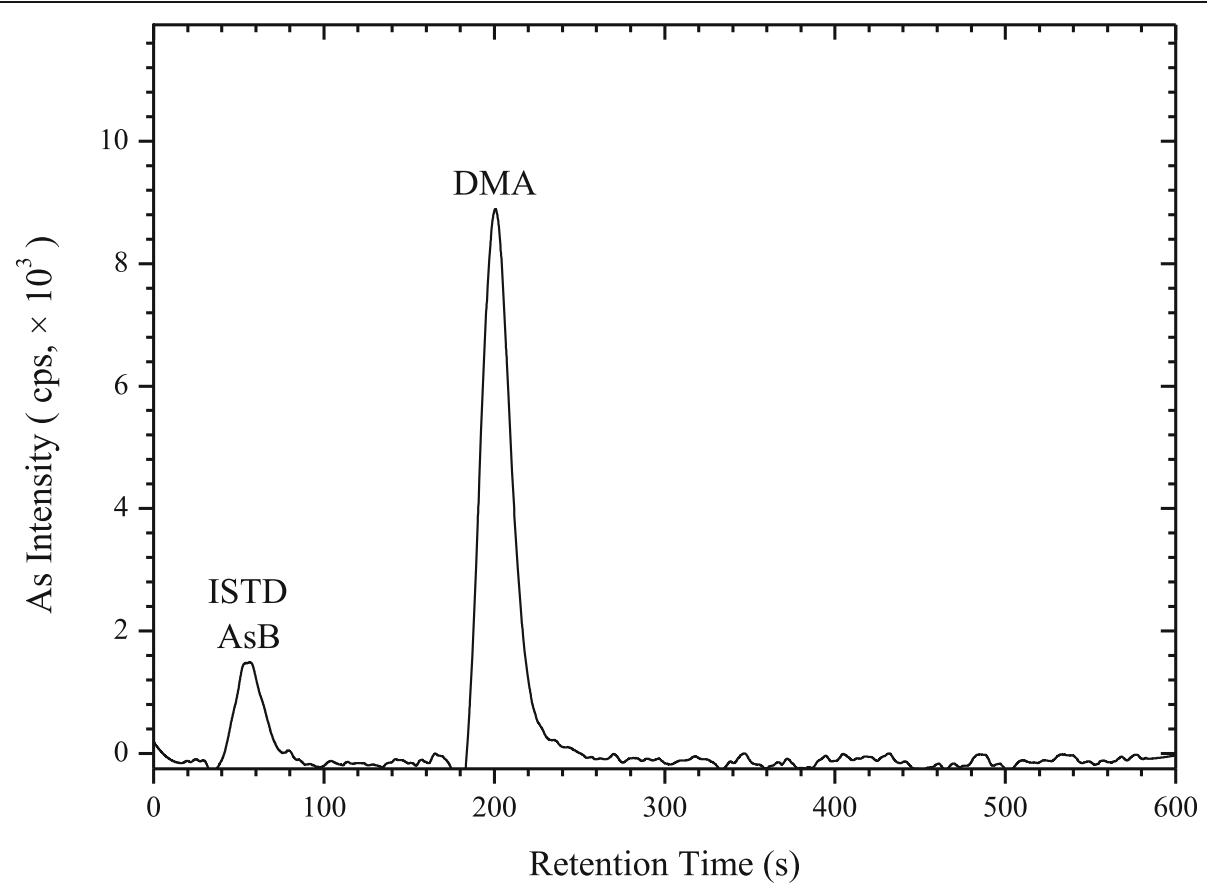

Fig. 4 Chromatogram of $100 \mu \mathrm{g} / \mathrm{kg}$ DMA and As(V) by IC-ICP-MS 
Table 4 Determination of DMA by IC-ICP-MS in solution

\begin{tabular}{lll}
\hline $\begin{array}{l}\text { Concentration of DMA } \\
(\boldsymbol{\mu g} / \mathbf{k g})\end{array}$ & $\begin{array}{l}\text { Results } \\
(\boldsymbol{\mu g} / \mathbf{k g})\end{array}$ & $\begin{array}{l}\text { Recovery } \\
(\%)\end{array}$ \\
\hline 16.8 & $17.4 \pm 2.0$ & 102.7 \\
78.6 & $81.8 \pm 8.6$ & 104.2 \\
809.4 & $878.7 \pm 72.3$ & 108.6 \\
\hline
\end{tabular}

DMA completely from $\mathrm{As}(\mathrm{V})$ by adsorbing the inorganic arsenic selectively.

\section{Conclusions}

Inorganic arsenic species, As(III) and As(V), dissolved in water was separated from the co-dissolved organoarsenic by the simple SPE method using an anion-exchange membrane filter. Before the filtration, one of the inorganic arsenic species, As(III), could be selectively oxidized to $\mathrm{As}(\mathrm{V})$ by hydrogen peroxide. The resulting $\mathrm{As}(\mathrm{V})$ that represents the total inorganic arsenics, As(III) and $\mathrm{As}(\mathrm{V})$, could be completely separated from the organoarsenic species. The ion-exchange membrane filter, on which the inorganic arsenics, As(III) and As(V), were adsorbed in forms of As(V), was analyzed by fs-LA-ICPMS. As $(V)$ was well and equally adsorbed on the surface of the filter. The RSD for the signal intensities of As(V) was estimated to be $1.2-5.3 \%$ in the concentration range from 0.5 to $1000 \mu \mathrm{g} / \mathrm{kg}$. The recovery efficiency of inorganic arsenic was ranged from 96 to $106 \%$. As the recovery of total inorganic, $\mathrm{As}(\mathrm{III})+\mathrm{As}(\mathrm{V})$, in the sample solution containing $\mathrm{As}(\mathrm{III}), \mathrm{As}(\mathrm{V})$, and DMA was $98 \%$. It indicated that the separation of $\mathrm{As}(\mathrm{V})$ from DMA was well completed by the anionic separator filter. The organoarsenic species in the filtered solution was quantitatively analyzed by IC-ICP-MS after the inorganic arsenic on the filter was quantified by fs-LA-ICP-MS. The linear dynamic range was obtained from 0.5 to $1000 \mu \mathrm{g} / \mathrm{kg}$. The LOD of inorganic arsenic was $0.028 \mu \mathrm{g} / \mathrm{kg}$, which is far below the MCL of arsenic in drinking water set by EPA. The detection limit of our SPE-fs-LA-ICP-MS method is much lower than that reported using SPELIBS by a factor of $3.6 \times 10^{5}$ and even lower than that obtained for the aqueous solution sample by the conventional IC-ICP-MS. This remarkable LOD performance can be attributed to the pre-concentration effect during the SPE process. Our results suggest that the combination of SPE and fs-LA-ICP-MS can be a simple and fast alternative for practical arsenic toxicity assessment for water at the level of parts per trillion.

\section{Abbreviations}

IC-ICP-MS: Ion chromatography inductively coupled plasma mass spectrometry; SPE: Solid phase extraction; fs-LA-ICP-MS: Femtosecond laser ablation inductively coupled plasma mass spectrometry; MMA: Monomethylarsonic acid; DMA: Dimethyl arsinic acid; AsB: Arsenobetaine;

AsC: Arsenocholine; JECFA: Joint FAO/WHO Expert Committee on Food Additives; SAX: Strongly anion exchange; WAX: Weakly anion exchange;
SCX: Strong cation exchange; WCX: Weakly cation exchange; LIBS: Laserinduced breakdown spectroscopy; LOD: Limit of detection; RSD: Relative standard deviation; EPA: Environmental Protection Agency; MCL: Maximum contamination level

\section{Acknowledgements}

This work was supported by the Korea Basic Science Institute (KBSI) National Research Facilities \& Equipment Center (NFEC) grant funded by the Korean government (Ministry of Education) (No. 2019R1A6C1010005) and the National Research Foundation of Korea (NRF) grant funded by the Korean government (MSIT) (No. 2019R1A2C1003069). The authors thank Dr. Sehoon Jeung and Ms. Sunhye Kim for their technical assistance.

\section{Authors' contributions}

SHN designed the study and directed all experiments. YL advised on LIBS support and measurement. The experiment was executed by SHL and SJY.

The authors read and approved the final manuscript.

\section{Funding}

No applicable.

Availability of data and materials

All data generated and analyzed in this study have been provided in the manuscript.

\section{Declarations}

\section{Competing interests}

The authors declare that they have no competing interests.

Received: 21 December 2020 Accepted: 21 June 2021

Published online: 13 July 2021

\section{References}

3M SPE Technical Information, Empore Solids Phase Extraction Disks, Extraction Method with Anion Exchange Disk. https://multimedia.3m.com/mws/media/ 5339700/emporetmsolid-phase-extraction-disk-anion-exchange-tech-info.pdf.

Arsenic and clarification to compliance and new source monitoring rule: a quick reference guide. United States Environmental Protection Agency. EPA 816-F01-004. 2001.

ATSDR. Arsenic toxicity: U.S Public Heal. Serv. Agency Toxic Subst. Dis. Regist; 2006.

ATSDR. Public health statement arsenic: U.S Public Heal. Serv. Agency Toxic Subst. Dis. Regist; 2007. p. 1-10.

Audi G, Bersillon O, Blachot J, Wapstra AH. The NUBASE evaluation of nuclear and decay properties. Nucl Phys A. 2003;729:3-128. https://doi.org/10.1016/j. nuclphysa.2003.11.001.

Chen G, Chen T. SPE speciation of inorganic arsenic in rice followed by hydridegeneration atomic fluorescence spectrometric quantification. Talanta. 2014; 119:202-6. https://doi.org/10.1016/j.talanta.2013.11.016.

Chichkov BN, Momma C, Nolte S, Alvensleben F, Tünnermann A. Femtosecond, picosecond and nanosecond laser ablation of solids. Appl Phys A Mater Sci Process. 1996;63:109-15. https://doi.org/10.1007/BF01567637.

Choi H, Park SK, Kim DS, Kim MH. Risk assessment of arsenic in agricultural products. Korean J Environ Agric. 2010;29:266-72. https://doi.org/10.5338/ KJEA.2010.29.3.266.

Cullen WR, Reimer KJ. Arsenic speciation in the environment. Chem Rev. 1989;89: 713-64. https://doi.org/10.1021/cr00094a002.

Diwakar PK, Harilal SS, Lahaye NL, Hassanein A, Kulkarni P. The influence of laser pulse duration and energy on ICP-MS signal intensity, elemental fractionation, and particle size distribution in NIR fs-LA-ICP-MS. J Anal At Spectrom. 2013;28:1420-9. https://doi.org/10.1039/c3ja50088h.

Flanagan S, Johnston R, Zheng Y. Arsenic in tube well water in Bangladesh: health and economic impacts and implications for arsenic mitigation. Bull World Health Organ. 2012;90:839-46. https://doi.org/10.2471/BLT.11.101253.

Haynes WM. CRC handbook of chemistry and physics. 97th ed: CRC Press; 2016. p. 14-7.

IARC. Arsenic, metals, fibers, and dusts, IARC Monographs Volume 100C: WHO Press; 2012. p. 42. 
Lahaye NL, Kurian J, Diwakar PK, Alff L, Harilal SS. Femtosecond laser ablation based mass spectrometry: an ideal tool for stoichiometric analysis of thin films. Sci Rep. 2015:1-8. https://doi.org/10.1038/srep13121.

Lee WB, Lee SH, Lee Y, Nam SH. Accurate measurement of total arsenic in rice and oyster by considering arsenic species. Bull Kor Chem Soc. 2019:1-5. https://doi.org/10.1002/bkcs.11889.

Li Z, Hu Z, Günther D, Zong K, Liu Y, Luo T, et al. Ablation characteristic of ilmenite using UV nanosecond and femtosecond lasers: implications for nonmatrix-matched quantification. Geostand Geoanal Res. 2016;40:477-91. https://doi.org/10.1111/ggr.12117.

Llorente-Mirandes T, Rubio R, López-Sánchez JF. Inorganic arsenic determination in food: a review of analytical proposals and quality assessment over the last six years. Appl Spectrosc. 2017;71:25-69. https://doi.org/10.1177/000370281 6652374

Martinez VD, Vucic EA, Becker-Santos DD, Gil L, Lam WL. Arsenic exposure and the induction of human cancer. J Toxicol. 2011;2011:431287. https://doi.org/1 $0.1155 / 2011 / 431287$.

Nam SH, Kim JJ, Han SS. Direct determination of total arsenic and arsenic species by ion chromatography coupled with inductively coupled plasma mass spectrometry. Bull Kor Chem Soc. 2003;24:1805-8. https://doi.org/10.5012/ bkcs.2003.24.12.1805.

Nam SH, Kwon SW, Lee Y. Feasibility of separation and quantification of inorganic arsenic species using ion-exchange membranes and laser-induced breakdown spectroscopy. Anal Lett. 2018;51:2833-46. https://doi.org/10.1080/ 00032719.2018 .1453517

Nazaratul A, Amares C. Determination of inorganic arsenic in natural water by solid phase extraction. INIS. 2011;44:2-8.

Ratnaike RN. Acute and chronic arsenic toxicity. Postgrad Med J. 2003;79:391-6. https://doi.org/10.1136/pmj.79.933.391.

Russo RE, Mao XL, Liu HC, Yoo JH, Mao SS. Time-resolved plasma diagnostics and mass removal during single-pulse laser ablation. Appl Phys A Mater Sc Process. 1999;69:887-94. https://doi.org/10.1007/s003390051553.

Son SH, Lee WB, Kim D, Lee Y, Nam SH. An alternative analytical method for determining arsenic species in rice by using ion chromatography and inductively coupled plasma-mass spectrometry. Food Chem. 2019;270:353-8. https://doi.org/10.1016/j.foodchem.2018.07.066.

Tamaki S, Frankenberger WT. Environmental biochemistry of arsenic. Rev Environ Contam Toxicol. 1992;124:79-110. https://doi.org/10.1007/978-1-4612-28646 .4.

Tamura K, Jansen RA, Eskridge PB, Cohen SH, Windhorst RA. Lifting the veil of dust from Ngc 0959: the importance of a pixel-based two-dimensional extinction correction. Astron J. 2010;139:2557-65. https://doi.org/10.1088/ 0004-6256/139/6/2557.

Todorov TI, Ejnik JW, Mullick FG, Centeno JA. Arsenic speciation in urine and blood reference materials. Microchim Acta. 2005;151:263-8. https://doi.org/1 0.1007/s00604-005-0414-8

Vanhaecke F, Resano M, Koch J, McIntosh K, Günther D. Femtosecond laser ablation-ICP-mass spectrometry analysis of a heavy metallic matrix: determination of platinum group metals and gold in lead fire-assay buttons as a case study. J Anal At Spectrom. 2010;25:1259-67. https://doi.org/10.103 9/c002746d.

Yang SH, Park JS, Cho MJ, Choi H. Risk analysis of inorganic arsenic in foods. J Food Hyg Saf. 2016;31:227-49. https://doi.org/10.13103/jhss.2016.31.4.227.

\section{Publisher's Note}

Springer Nature remains neutral with regard to jurisdictional claims in published maps and institutional affiliations.

\section{Submit your manuscript to a SpringerOpen ${ }^{\circ}$ journal and benefit from:}

- Convenient online submission

- Rigorous peer review

- Open access: articles freely available online

High visibility within the field

- Retaining the copyright to your article

Submit your next manuscript at $\boldsymbol{\nabla}$ springeropen.com 